\title{
Binuclear Phospholyl Iron Carbonyls: The Limited Role of the Phosphorus Atom in Metal Complexation
}

\author{
Xiaohong Chen, ${ }^{\mathrm{a}} \mathrm{Li}$ Yuan, ${ }^{\mathrm{a}}$ Guiming Ren, ${ }^{\mathrm{a}}$ Qiao Xi, ${ }^{\mathrm{a}}$ Rong Jin, ${ }^{\mathrm{a}}$ Quan Du, ${ }^{\mathrm{a}}$ \\ Hao Feng, ${ }^{a *}$ Yaoming Xie, ${ }^{b}$ and R. Bruce King, ${ }^{\text {b* }}$ \\ ${ }^{a}$ School of Physics and Chemistry, Research Center for Advanced Computation, \\ Xihua University, Chengdu, China 610039 \\ ${ }^{b}$ Department of Chemistry and Center for Computational Chemistry \\ University of Georgia, Athens, Georgia 30602, USA \\ E-mail: Fenghao@mail.xhu.edu.cn; rbking@chem.uga.edu
}

\begin{abstract}
The structures and thermodynamics of the binuclear phospholyliron carbonyls $\left(\mathrm{C}_{4} \mathrm{H}_{4} \mathrm{P}\right)_{2} \mathrm{Fe}_{2}(\mathrm{CO})_{n}(n=6,5,4,3,2)$ have been investigated using density functional theory. The low-energy $\left(\mathrm{C}_{4} \mathrm{H}_{4} \mathrm{P}\right)_{2} \mathrm{Fe}_{2}(\mathrm{CO})_{n}(n=4,3,2)$ structures are found to have direct iron-iron bonds and terminal five-electron donor pentahapto $\eta^{5}-\mathrm{C}_{4} \mathrm{H}_{4} \mathrm{P}$ rings with the phosphorus lone pairs not involved in the bonding to the iron atoms. They are thus analogous to the corresponding cyclopentadienyliron carbonyl derivatives. However, they differ from the binuclear phospholyl manganese carbonyls $\left(\mathrm{C}_{4} \mathrm{H}_{4} \mathrm{P}\right)_{2} \mathrm{Mn}_{2}(\mathrm{CO})_{n}(n=5$, 4) for which structures with bridging seven-electron donor $\eta^{5}, \eta^{1}-\mathrm{C}_{4} \mathrm{H}_{4} \mathrm{P}$ phospholyl rings are the lowest energy structures by substantial margins. Partially bonded phospholyl rings, as well as direct Fe-Fe bonds, are found in the carbonyl-rich $\left(\mathrm{C}_{4} \mathrm{H}_{4} \mathrm{P}\right)_{2} \mathrm{Fe}_{2}(\mathrm{CO})_{n}(n=6,5)$ species. The pentacarbonyl $\left(\mathrm{C}_{4} \mathrm{H}_{4} \mathrm{P}\right)_{2} \mathrm{Fe}_{2}(\mathrm{CO})_{5}$ does not appear to be a viable species since it is disfavored relative to $\mathrm{CO}$ loss and to disproportionation into $\left(\mathrm{C}_{4} \mathrm{H}_{4} \mathrm{P}\right)_{2} \mathrm{Fe}_{2}(\mathrm{CO})_{6}$ $+\left(\mathrm{C}_{4} \mathrm{H}_{4} \mathrm{P}\right)_{2} \mathrm{Fe}_{2}(\mathrm{CO})_{4}$.
\end{abstract}




\section{Introduction}

The chemistry of cyclopentadienyliron carbonyls dates back 60 years to the synthesis of $\left(\eta^{5}-\mathrm{C}_{5} \mathrm{H}_{5}\right)_{2} \mathrm{Fe}_{2}(\mathrm{CO})_{2}(\mu-\mathrm{CO})_{2}$ by Piper and Wilkinson in 1956 from the thermal reaction of $\mathrm{Fe}(\mathrm{CO})_{5}$ with cyclopentadiene dimer at $\sim 130^{\circ} \mathrm{C}[1]$. Subsequently both cis and trans stereoisomers of $\left(\eta^{5}-\mathrm{C}_{5} \mathrm{H}_{5}\right)_{2} \mathrm{Fe}_{2}(\mathrm{CO})_{2}(\mu-\mathrm{CO})_{2}$ were separated and structurally characterized by X-ray crystallography [2, 3, 4].

Interesting species have been obtained by decarbonylation of $\left(\eta^{5}-\mathrm{C}_{5} \mathrm{H}_{5}\right)_{2} \mathrm{Fe}_{2}(\mathrm{CO})_{2}(\mu-\mathrm{CO})_{2}$. Photolysis under mild conditions gives the unsaturated $\left(\eta^{5}-\mathrm{C}_{5} \mathrm{H}_{5}\right)_{2} \mathrm{Fe}_{2}(\mu-\mathrm{CO})_{3}[5,6,7]$, which is of interest as a stable triplet spin state metal carbonyl derivative. X-ray crystallography of the permethylated derivative $\left(\eta^{5}-\mathrm{Me}_{5} \mathrm{C}_{5}\right)_{2} \mathrm{Fe}_{2}(\mu-\mathrm{CO})_{3}$ indicates a short $\mathrm{Fe}=\mathrm{Fe}$ distance of $2.265 \AA$, interpreted to be the formal double bond required to give each iron atom the favored 18-electron configuration [8]. Further decarbonylation of $\left(\eta^{5}-\mathrm{C}_{5} \mathrm{H}_{5}\right)_{2} \mathrm{Fe}_{2}(\mathrm{CO})_{2}(\mu-\mathrm{CO})_{2}$ by prolonged pyrolysis at $\sim 100^{\circ} \mathrm{C}$ leads to the tetranuclear cluster $\left(\eta^{5}-\mathrm{C}_{5} \mathrm{H}_{5}\right)_{4} \mathrm{Fe}_{4}\left(\mu_{3}-\mathrm{CO}\right)_{4}$ containing a central $\mathrm{Fe}_{4}$ tetrahedron with each face capped by a carbonyl group [9]. Theoretical studies on $\left(\eta^{5}-\mathrm{C}_{5} \mathrm{H}_{5}\right)_{2} \mathrm{Fe}_{2}(\mathrm{CO})_{n}(n=4,3,2)$ derivatives [10] suggest the formation of this cluster by dimerization of an unsaturated doubly bridged $\left(\eta^{5}-\mathrm{C}_{5} \mathrm{H}_{5}\right)_{2} \mathrm{Fe}_{2}(\mu-\mathrm{CO})_{2}$ with a short $\mathrm{Fe} \equiv \mathrm{Fe}$ distance of $\sim 2.13 \AA$ consistent with the formal triple bond required to give each iron atom the favored 18-electron configuration.

The analogy between a bare phosphorus atom and a $\mathrm{CH}$ moiety [11] makes the phospholyl (phosphacyclopentadienyl) ligand, $\eta^{5}-\mathrm{C}_{4} \mathrm{H}_{4} \mathrm{P}$, an analogue of the cyclopentadienyl ligand. Because of synthetic challenges, development of phospholylmetal chemistry lagged considerably behind the development of cyclopentadienylmetal chemistry. However, Mathey and coworkers [12, 13] used the thermal reaction of P-phenylphosphole with $\mathrm{Mn}_{2}(\mathrm{CO})_{10}$ to synthesize phospholylmanganese tricarbonyl $\left(\eta^{4}-\mathrm{C}_{4} \mathrm{H}_{4} \mathrm{P}\right) \mathrm{Mn}(\mathrm{CO})_{3}$. Comparison of the properties of $\left(\eta^{5}-\mathrm{C}_{4} \mathrm{H}_{4} \mathrm{P}\right) \mathrm{Mn}(\mathrm{CO})_{3}$ and $\left(\eta^{5}-\mathrm{C}_{5} \mathrm{H}_{5}\right) \mathrm{Mn}(\mathrm{CO})_{3}$ showed that substitution of one of the $\mathrm{CH}$ moieties in the fivemembered ring with a phosphorus atom leads to very little change in physiochemical properties such as color, odor, melting point, solubility, elution rate, and reactivity with electrophiles. However, the lone pair remaining on the phosphorus atom in the phospholyl ring makes $\left(\eta^{5}-\mathrm{C}_{4} \mathrm{H}_{4} \mathrm{P}\right) \mathrm{Mn}(\mathrm{CO})_{3}$ a ligand to a second transition metal to form a binuclear metal complex. Thus in a binuclear derivative a phospholyl ligand can act as a seven-electron donor bridging ligand across a central $\mathrm{M}_{2}$ or $\mathrm{MM}$ ' unit by using the phosphorus lone pair electrons in addition to the five $\pi$-electrons of the phospholyl ring (Figure 1). This possibility of a phospholyl ligand acting as a seven-electron donor 
bridge across an $\mathrm{M}_{2}$ unit suggested that binuclear phospholyl metal carbonyls might have significantly different chemistry than the corresponding cyclopentadienyl metal carbonyls.

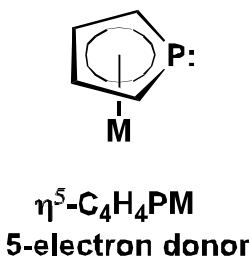

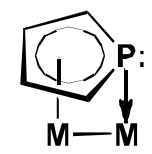

$\eta^{5}{ }_{,} \eta^{1}-\mu-C_{4} \mathrm{H}_{4} \mathrm{PM}$

5-electron donor:

M-M bond

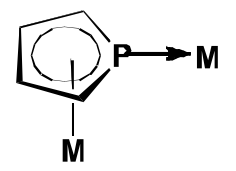

$\eta^{5} \eta^{1}-\mu-C_{4} \mathrm{H}_{4} \mathrm{PM}$

7-electron donor:

no $M-M$ bond

Figure 1. The phospholyl ligand as a five-electron and a seven-electron donor in transition metal complexes.

In previous papers we have used density functional theory to investigate the mononuclear and binuclear phospholylmetal carbonyls of the transition metals manganese and cobalt of odd atomic number. For manganese the lowest energy $\left(\mathrm{C}_{4} \mathrm{H}_{4} \mathrm{P}\right)_{2} \mathrm{Mn}_{2}(\mathrm{CO})_{5}$ and $\left(\mathrm{C}_{4} \mathrm{H}_{4} \mathrm{P}\right)_{2} \mathrm{Mn}_{2}(\mathrm{CO})_{4}$ structures by a wide margin were found to have one and two seven-electron donor bridging $\eta^{5}, \eta^{1}-\mathrm{C}_{4} \mathrm{H}_{4} \mathrm{P}$ phospholyl rings, respectively, thereby avoiding the need for an $\mathrm{Mn}-\mathrm{Mn}$ bond to give each manganese atom the favored 18-electron configuration [14]. However, the lowest energy structure for the tricarbonyl $\left(\mathrm{C}_{4} \mathrm{H}_{4} \mathrm{P}\right)_{2} \mathrm{Mn}_{2}(\mathrm{CO})_{3}$ is a triply bridged $\left(\eta^{5}-\mathrm{C}_{4} \mathrm{H}_{4} \mathrm{P}\right)_{2} \mathrm{Mn}_{2}(\mu-\mathrm{CO})_{3}$ structure with terminal five-electron donor $\eta^{5}-\mathrm{C}_{4} \mathrm{H}_{4} \mathrm{P}$ phospholyl rings in which their phosphorus external lone pairs are not involved in the manganese-ligand bonding. This $\left(\eta^{5}-\mathrm{C}_{4} \mathrm{H}_{4} \mathrm{P}\right)_{2} \mathrm{Mn}_{2}(\mu-\mathrm{CO})_{3}$ structure is analogous to that of the stable compound $\left(\eta^{5}-\mathrm{Me}_{5} \mathrm{C}_{5}\right)_{2} \mathrm{Mn}_{2}(\mu-\mathrm{CO})_{3}$, shown by X-ray crystallography to have a very short $\mathrm{Mn} \equiv \mathrm{Mn}$ distance corresponding to the formal triple bond required to give each manganese atom the favored 18-electron configuration.[15]

The binuclear phospholylcobalt carbonyls were found to be very different from the phospholylmanganese carbonyls in not having seven-electron donor bridging $\eta^{1}, \eta^{5}-\mathrm{C}_{4} \mathrm{H}_{4} \mathrm{P}$ rings in their energetically favored structures [16]. Thus the lowest energy $\left(\mathrm{C}_{4} \mathrm{H}_{4} \mathrm{P}\right)_{2} \mathrm{Co}_{2}(\mathrm{CO})_{n}(n=3,2,1)$ structures were all found to have five-electron donor terminal $\eta^{5}-\mathrm{C}_{4} \mathrm{H}_{4} \mathrm{P}$ rings rather than seven-electron donor bridging $\eta^{5}, \eta^{1}$-phospholyl rings. In fact these lowest energy $\left(\mathrm{C}_{4} \mathrm{H}_{4} \mathrm{P}\right)_{2} \mathrm{Co}_{2}(\mathrm{CO})_{n}(n=3,2,1)$ structures were found to be completely analogous to the isoelectronic phosphorus-free structures $\left(\mathrm{C}_{5} \mathrm{H}_{5}\right)_{2} \mathrm{Co}_{2}(\mathrm{CO})_{n}(n$ $=3,2,1)$, which have been synthesized $[17,18]$ and studied by density functional theory [19]. In addition, higher energy $\left(\mathrm{C}_{4} \mathrm{H}_{4} \mathrm{P}\right)_{2} \mathrm{Co}_{2}(\mathrm{CO})_{n}(n=3,2,1)$ structures were found in 
which the phospholyl ligand acts as a five-electron donor $\eta^{5}, \eta^{1}-\mathrm{C}_{4} \mathrm{H}_{4} \mathrm{P}$ ligand across a Co-Co bond (Figure 1).

This paper presents a theoretical study of the phospholyl metal carbonyl derivatives of iron, as a representative transition metal of even atomic number. Even though phospholyl iron carbonyls have not yet been synthesized, iron was chosen for this study to provide a comparison of the $\left(\mathrm{C}_{4} \mathrm{H}_{4} \mathrm{P}\right)_{2} \mathrm{Fe}_{2}(\mathrm{CO})_{n}(n=4,3,2)$ derivatives with their extensively studied cyclopentadienyl derivatives $\left(\mathrm{C}_{5} \mathrm{H}_{5}\right)_{2} \mathrm{Fe}_{2}(\mathrm{CO})_{n}(n=4,3,2)$ as noted above. A possible synthetic entry into these species would be reactions of one equivalent of a phospholyl anion with the readily available $\mathrm{Fe}(\mathrm{CO})_{4} \mathrm{I}_{2}$ to give a phospholyliron carbonyl iodide such as the unsubstituted $\left(\mathrm{C}_{4} \mathrm{H}_{4} \mathrm{P}\right) \mathrm{Fe}(\mathrm{CO})_{2} \mathrm{I}$. Reductive deiodination of such species could then provide the binuclear $\left(\mathrm{C}_{4} \mathrm{H}_{4} \mathrm{P}\right)_{2} \mathrm{Fe}_{2}(\mathrm{CO})_{4}$ analogous to $\left(\eta^{5}-\mathrm{C}_{5} \mathrm{H}_{5}\right)_{2} \mathrm{Fe}_{2}(\mathrm{CO})_{4}$.

\section{Theoretical Methods}

Electron correlation effects were considered by employing density functional theory (DFT) methods, which have evolved as a practical and effective computational tool, especially for organometallic compounds $[20,21,22,23,24,25,26]$. Thus two DFT methods were used in this study. The first method uses the B3LYP hybrid functional, which combines the three-parameter Becke functional (B3) with the LeeYang-Parr (LYP) generalized gradient correlation functional [27, 28]. The other DFT method used in the present paper is BP86, which combines Becke's 1988 exchange functional (B) with Perdew's 1986 gradient corrected correlation functional method (P86) [29, 30].

The B3LYP and BP86 methods agree with each other fairly well in predicting the structural characteristics of the $\left(\mathrm{C}_{4} \mathrm{H}_{4} \mathrm{P}\right)_{2} \mathrm{Fe}_{2}(\mathrm{CO})_{n}$ derivatives of interest. However, the B3LYP and BP86 methods predict quite different singlet-triplet splittings. This is not unusual, since Reiher and collaborators [31] have found that the B3LYP predictions always favor the high-spin state whereas the BP86 prediction favors the low-spin state, with the true value lying between the B3LYP and BP86 predictions. For this reason, they proposed a new parametrization for the B3LYP functional, namely B3LYP*, which provides electronic state orderings in closer agreement with experiment. These same authors also tested this B3LYP* functional with the G2 test set and obtained satisfactory results [32]. In the present paper, since the B3LYP and BP86 methods predict different singlet-triplet splittings, we also used the B3LYP* method to give more reliable energy differences between the singlet and triplet structures as well as more reliable dissociation energies. 
The present report lists the values from all three DFT methods. For the $v(C O)$ vibrational frequencies, the B3LYP method usually predicts higher values than the BP86 method by $\sim 100 \mathrm{~cm}^{-1}$. Previous work shows that the BP86 results are closer to the experimental $v(\mathrm{CO})$ values without using any scaling factors [33,34]. This concurrence may be accidental, since the theoretical vibrational frequencies predicted by BP86 are harmonic frequencies, whereas the experimental fundamental frequencies are anharmonic.

All computations were performed using the double- $\zeta$ plus polarization (DZP) basis sets. The DZP basis sets used for carbon and oxygen add one set of pure spherical harmonic $d$ functions with orbital exponents $\alpha_{d}(C)=0.75$ and $\alpha_{d}(O)=0.85$ to the standard Huzinaga-Dunning contracted DZ sets [35,36] and are designated (9s5p1d/4s2p1d). The DZP basis set used for phosphorus adds one set of pure spherical harmonic $d$ functions with orbital exponents $\alpha_{d}(P)=0.60$ to the standard HuzinagaDunning contracted DZ sets and are designated (12s8p1d/6s4p1d). For hydrogen, a set of $\mathrm{p}$ polarization functions $\alpha_{\mathrm{p}}(\mathrm{H})=0.75$ is added to the Huzinaga-Dunning DZ set. The loosely contracted DZP basis set for iron is the Wachters primitive set [37] augmented by two sets of $\mathrm{p}$ functions and a set of $\mathrm{d}$ functions, contracted following Hood, Pitzer, and Schaefer [38], designated (14s11p6d/10s8p3d).

The geometries of all structures were fully optimized using all three DFT methods. The vibrational frequencies were determined by evaluating analytically the second derivatives of the energy with respect to the nuclear coordinates. The corresponding infrared intensities were also evaluated analytically. All of the computations were carried out with the Gaussian 09 program [39], exercising the fine grid option (75 radial shells, 302 angular points) for evaluating integrals numerically [40].

\section{Results and Discussion}

\subsection{Molecular Structures}

3.1.1 $\left(\mathrm{C}_{4} \mathrm{H}_{4} \mathrm{P}\right)_{2} \mathrm{Fe}_{2}(\mathrm{CO})_{4}$. Eight low-energy structures were found for $\left(\mathrm{C}_{4} \mathrm{H}_{4} \mathrm{P}\right)_{2} \mathrm{Fe}_{2}(\mathrm{CO})_{4}$; all of these structures are singlets (Figure 2). Triplet $\left(\mathrm{C}_{4} \mathrm{H}_{4} \mathrm{P}\right)_{2} \mathrm{Fe}_{2}(\mathrm{CO})_{4}$ structures were also found. However, they are not discussed in this paper since the lowest energy triplet structure is predicted to lie more than $30 \mathrm{kcal} / \mathrm{mol}$ above the lowest energy singlet structure using the B3LYP* method. Thus triplet $\left(\mathrm{C}_{4} \mathrm{H}_{4} \mathrm{P}\right)_{2} \mathrm{Fe}_{2}(\mathrm{CO})_{4}$ structures are not likely to be chemically significant.

The $\left(\mathrm{C}_{4} \mathrm{H}_{4} \mathrm{P}\right)_{2} \mathrm{Fe}_{2}(\mathrm{CO})_{4}$ global minimum, $4 \mathrm{~S}-\mathbf{1}$, is a cis structure with two bridging $\mathrm{CO}$ groups and two terminal $\mathrm{CO}$ groups (Figure 2 and Table 1). Each $\eta^{5}-\mathrm{C}_{4} \mathrm{H}_{4} \mathrm{P}$ ring is bonded to a single $\mathrm{Fe}$ atom as a pentahapto ligand similar to the cyclopentadienyl ligand. The $\mathrm{Fe}-\mathrm{Fe}$ distance of $2.573 \AA$ (B3LYP*) is similar to the experimental distance of 
$2.54 \AA$ for the cyclopentadienyl analogue $\left(\eta^{5}-\mathrm{C}_{5} \mathrm{H}_{5}\right)_{2} \mathrm{Fe}_{2}(\mu-\mathrm{CO})_{2}(\mathrm{CO})_{2}$ and suggests a similar formal single bond. This gives each iron atom in $\mathbf{4 S - 1}$ the favored 18-electron configuration. The $\left(\mathrm{C}_{4} \mathrm{H}_{4} \mathrm{P}\right)_{2} \mathrm{Fe}_{2}(\mu-\mathrm{CO})_{2}(\mathrm{CO})_{2}$ structure $4 \mathrm{~S}-2\left(C_{2}\right)$, lying only $1.2 \mathrm{kcal} / \mathrm{mol}$ (B3LYP*) in energy above $\mathbf{4 S - 1}$, differs from $\mathbf{4 S - 1}$ only in the relative orientation of the phosphorus atoms in the $\eta^{5}-\mathrm{C}_{4} \mathrm{H}_{4} \mathrm{P}$ rings.
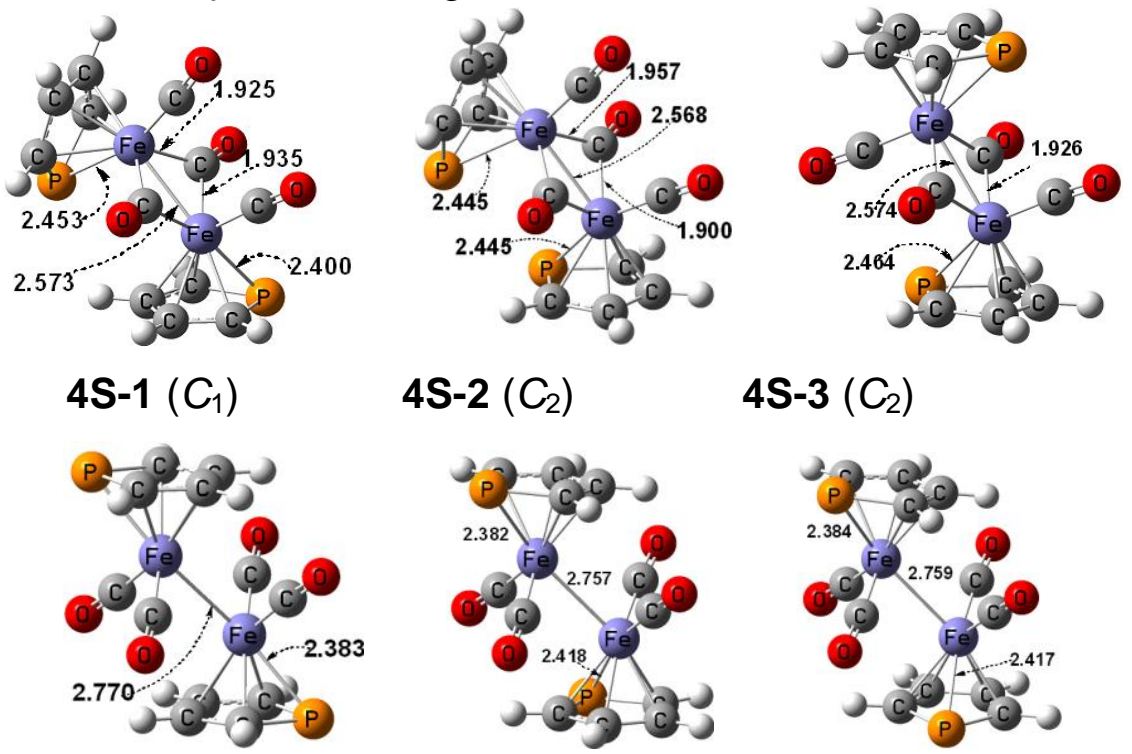

4S-2 $\left(C_{2}\right)$

4S-3 $\left(C_{2}\right)$

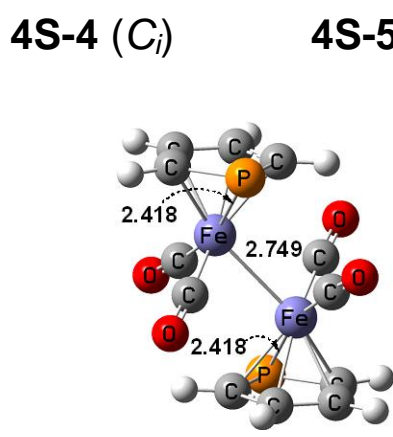

4S-7 $\left(C_{i}\right)$
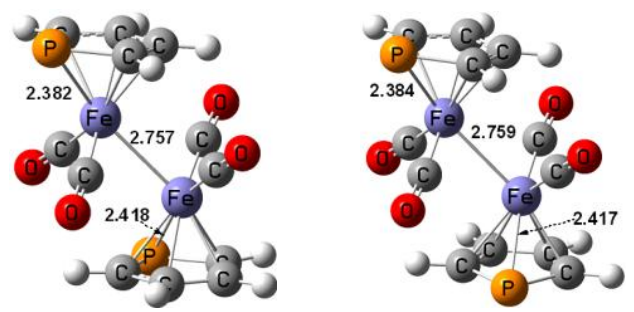

4S-5 $\left(C_{1}\right)$

4S-6 $\left(C_{1}\right)$

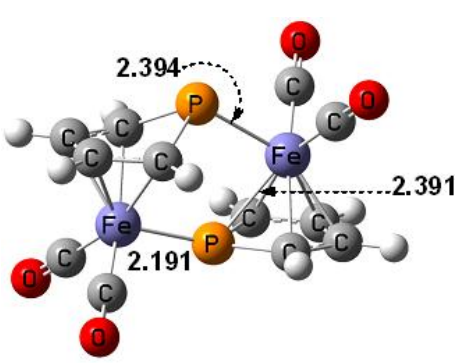

4S-8 $\left(C_{1}\right)$

Figure 2. The eight lowest-energy singlet $\left(\mathrm{C}_{4} \mathrm{H}_{4} \mathrm{P}\right)_{2} \mathrm{Fe}_{2}(\mathrm{CO})_{4}$ structures.

Table 1. Total energies ( $\mathrm{E}$, in hartree), relative energies $(\Delta \mathrm{E}$, in $\mathrm{kcal} / \mathrm{mol})$, and $\mathrm{Fe}-\mathrm{Fe}$ distances $(\AA)$ for the $\left(\mathrm{C}_{4} \mathrm{H}_{4} \mathrm{P}\right)_{2} \mathrm{Fe}_{2}(\mathrm{CO})_{4}$ structures. None of these structures has any imaginary vibrational frequencies.

\begin{tabular}{lcccccccc}
\hline \hline & $\begin{array}{c}\mathbf{4 S - 1} \\
\left(C_{1},{ }^{1} \mathrm{~A}\right)\end{array}$ & $\begin{array}{c}\mathbf{4 S - 2} \\
\left(C_{2},{ }^{1} \mathrm{~A}\right)\end{array}$ & $\begin{array}{c}\mathbf{4 S - 3} \\
\left(C_{2},{ }^{1} \mathrm{~A}_{\mathrm{g}}\right)\end{array}$ & $\begin{array}{c}\mathbf{4 S - 4} \\
\left(C_{i},{ }^{1} \mathrm{~A}_{\mathrm{g}}\right)\end{array}$ & $\begin{array}{c}\mathbf{4 S - 5} \\
\left(C_{1},{ }^{1} \mathrm{~A}\right)\end{array}$ & $\begin{array}{c}\mathbf{4 S - 6} \\
\left(C_{1},{ }^{1} \mathrm{~A}\right)\end{array}$ & $\begin{array}{c}\mathbf{4 S - 7} \\
\left(C_{\mathrm{i}},{ }^{1} \mathrm{~A}_{\mathrm{g}}\right)\end{array}$ & $\begin{array}{c}\mathbf{4 S - 8} \\
\left(C_{1}{ }^{1} \mathrm{~A}\right)\end{array}$ \\
\hline B3LYP* & & & & & & & & \\
$-(\mathrm{E}+3972)$ & 0.47734 & 0.47536 & 0.47326 & 0.47327 & 0.47194 & 0.47174 & 0.47021 & 0.46102 \\
$\Delta \mathrm{E}$ & 0.0 & 1.2 & 2.6 & 2.6 & 3.4 & 3.5 & 4.5 & 10.2 \\
$\mathrm{Fe}-\mathrm{Fe}$ & 2.573 & 2.568 & 2.574 & 2.770 & 2.757 & 2.759 & 2.749 & 3.871 \\
\hline
\end{tabular}


The $\left(\mathrm{C}_{4} \mathrm{H}_{4} \mathrm{P}\right)_{2} \mathrm{Fe}_{2}(\mathrm{CO})_{4}$ structure 4S-3, lying $2.6 \mathrm{kcal} / \mathrm{mol}(\mathrm{B} 3 \mathrm{LYP} *)$ in energy above $\mathbf{4 S - 1}$, is a trans structure with two bridging $\mathrm{CO}$ groups, two terminal $\mathrm{CO}$ groups, and two terminal $\eta^{5}-\mathrm{C}_{4} \mathrm{H}_{4} \mathrm{P}$ rings (Figure 2 and Table 1). The predicted $\mathrm{Fe}-\mathrm{Fe}$ distance of $2.574 \AA$ (B3LYP*) suggests a formal single bond thereby giving each iron atom the favored 18-electron configuration.

The $\left(\mathrm{C}_{4} \mathrm{H}_{4} \mathrm{P}\right)_{2} \mathrm{Fe}_{2}(\mathrm{CO})_{4}$ structures $4 \mathrm{~S}-4\left(C_{i}\right), 4 \mathrm{~S}-5\left(C_{1}\right), 4 \mathrm{~S}-6\left(C_{1}\right)$, and 4S-7 $\left(C_{i}\right)$ are all low-energy unbridged structures lying within $5 \mathrm{kcal} / \mathrm{mol}$ of $\mathbf{4 S - 1}$ with each iron atom bearing two terminal $\mathrm{CO}$ groups (Figure 2 and Table 1). These structures differ in the relative orientation of their ring phosphorus atoms. The unbridged $\mathrm{Fe}-\mathrm{Fe}$ distances in these structures of $\sim 2.75 \AA$ are significantly longer than the doubly bridged $\mathrm{Fe}-\mathrm{Fe}$ distances in the $\left(\mathrm{C}_{4} \mathrm{H}_{4} \mathrm{P}\right)_{2} \mathrm{Fe}_{2}(\mathrm{CO})_{4}$ structures $4 \mathrm{~S}-1, \mathbf{4 S}-2$, and $4 \mathrm{~S}-3$ but still suggest formal single bonds thereby giving each iron atom the favored 18-electron configuration.

The $\left(\mathrm{C}_{4} \mathrm{H}_{4} \mathrm{P}\right)_{2} \mathrm{Fe}_{2}(\mathrm{CO})_{4}$ structure $4 \mathrm{~S}-8$, lying $10.2 \mathrm{kcal} / \mathrm{mol}(\mathrm{B} 3 \mathrm{LYP} *)$ in energy above 4S-1, has two terminal $\mathrm{CO}$ groups bonded to each iron atom, two bridging $\mathrm{C}_{4} \mathrm{H}_{4} \mathrm{P}$ rings, and a non-bonding $\mathrm{Fe}{ }^{\cdots} \mathrm{Fe}$ distance of $3.871 \AA$ (B3LYP*). One phospholyl ring is a $\eta^{5}, \eta^{1}$-ligand bonded to one iron atom as a pentahapto ligand and to the other iron atom through a $\mathrm{P} \rightarrow \mathrm{Fe}$ dative bond of length $2.191 \AA$ (B3LYP*), thus functioning as a sevenelectron donor to the central $\mathrm{Fe}_{2}$ unit. The other phospholyl ring is a $\eta^{4}, \eta^{1}$-ligand bonded to one iron atom as a tetrahapto ligand and to the other iron atom through a normal P-Fe covalent bond of length $2.394 \AA$, thereby functioning as a five-electron donor ligand to the central $\mathrm{Fe}_{2}$ unit. This combination of ligands and the lack of an ironiron bond in $\mathbf{4 S - 8}$ give each iron atom the favored 18-electron configuration.

3.1.2. $\left(\mathrm{C}_{4} \mathrm{H}_{4} \mathrm{P}\right)_{2} \mathrm{Fe}_{2}(\mathrm{CO})_{3}$. Seven low energy $\left(\mathrm{C}_{4} \mathrm{H}_{4} \mathrm{P}\right)_{2} \mathrm{Fe}_{2}(\mathrm{CO})_{3}$ structures were found, namely one singlet and six triplets (Figure 3 and Table 2). The lowest energy $\left(\mathrm{C}_{4} \mathrm{H}_{4} \mathrm{P}\right)_{2} \mathrm{Fe}_{2}(\mathrm{CO})_{3}$ structure 3T-1 has a single bridging $\mathrm{CO}$ group, a terminal five-electron donor pentahapto $\eta^{5}-\mathrm{C}_{4} \mathrm{H}_{4} \mathrm{P}$ ring, and a bridging seven-electron donor $\eta^{1}, \eta^{5}-\mathrm{C}_{4} \mathrm{H}_{4} \mathrm{P}$ ring bonded as a pentahapto ligand to one iron atom and through a $\mathrm{P} \rightarrow \mathrm{Fe}$ dative bond to the other iron atom. The predicted $\mathrm{Fe}-\mathrm{Fe}$ distance of 2.609 $\AA$ (B3LYP*), suggests the formal single bond required to give each iron atom the favored 18-electron configuration.

The $\left(\mathrm{C}_{4} \mathrm{H}_{4} \mathrm{P}\right)_{2} \mathrm{Fe}_{2}(\mathrm{CO})_{3}$ structure 3T-2, lying only $1.0 \mathrm{kcal} / \mathrm{mol}(\mathrm{B} 3 \mathrm{LYP} *)$ in energy above 3T-2, has three bridging $\mathrm{CO}$ groups and two $\eta^{5}-\mathrm{C}_{4} \mathrm{H}_{4} \mathrm{P}$ rings and is closely related to the known cyclopentadienyl derivatives $\left(\eta^{5}-\mathrm{C}_{5} \mathrm{R}_{5}\right)_{2} \mathrm{Fe}_{2}(\mu-\mathrm{CO})_{3}\left(\mathrm{R}=\mathrm{H}, \mathrm{CH}_{3}\right)[5$, $6,7,8]$. The $\mathrm{Fe}=\mathrm{Fe}$ distance of $2.270 \AA$ (B3LYP*) in 3T-2 is very similar to the experimental $\mathrm{Fe}=\mathrm{Fe}$ distance of $2.265 \AA$ in $\left(\eta^{5}-\mathrm{Me}_{5} \mathrm{C}_{5}\right)_{2} \mathrm{Fe}_{2}(\mu-\mathrm{CO})_{3}$ suggesting a similar formal double $\sigma+2 / 2 \pi$ bond. This gives each iron atom in 3T-2 the favored 18 -electron 
configuration. The two unpaired electrons in the triplet spin state of 3T-2 reside in the formal double bond as two orthogonal $\pi$ half-bonds similar to that suggested for the $\left(\eta^{5}-\mathrm{R}_{5} \mathrm{C}_{5}\right)_{2} \mathrm{Fe}_{2}(\mu-\mathrm{CO})_{3}$ derivatives. The $\left(\mathrm{C}_{4} \mathrm{H}_{4} \mathrm{P}\right)_{2} \mathrm{Fe}_{2}(\mathrm{CO})_{3}$ structure 3T-3, with $C_{2 v}$ symmetry, has almost the same total energy and geometrical configuration as 3T-2 except for the relative orientation of the ring phosphorus atoms..

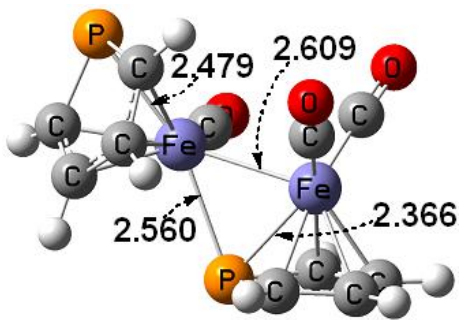

3T-1_( $\left(C_{1}\right)$

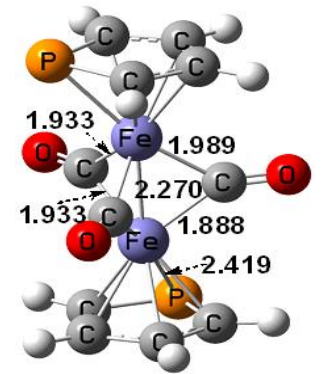

3T-2 $\left(C_{2}\right)$
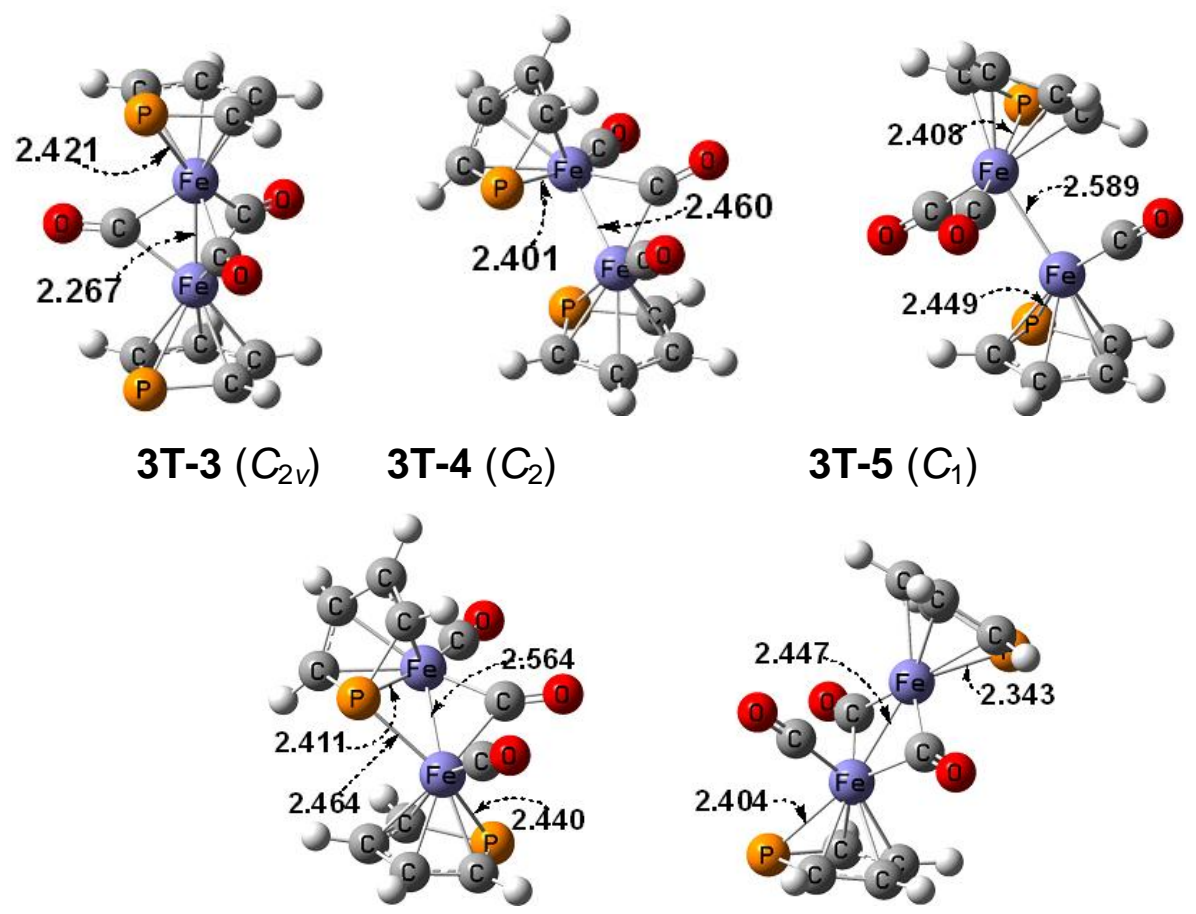

3T-6 $\left(C_{1}\right)$

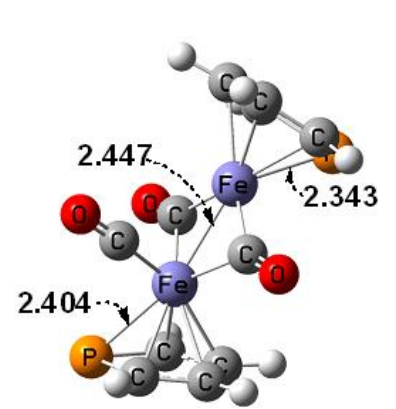

3S-1 $\left(C_{1}\right)$

Figure 3. The seven lowest-energy $\left(\mathrm{C}_{4} \mathrm{H}_{4} \mathrm{P}\right)_{2} \mathrm{Fe}_{2}(\mathrm{CO})_{3}$ structures.

The $\left(\mathrm{C}_{4} \mathrm{H}_{4} \mathrm{P}\right)_{2} \mathrm{Fe}_{2}(\mathrm{CO})_{3}$ structure 3T-4, lying $5.2 \mathrm{kcal} / \mathrm{mol}(\mathrm{B} 3 \mathrm{LYP} *)$ in energy above 3T-1, has one bridging $\mathrm{CO}$ group, two terminal $\mathrm{CO}$ groups, and terminal pentahapto $\eta^{5}-\mathrm{C}_{4} \mathrm{H}_{4} \mathrm{P}$ rings (Figure 3 and Table 2). The Fe-Fe distance of $2.460 \AA$ (B3LYP*) in 3T-4 suggests a formal single bond thereby giving each iron atom a 17-electron configuration for a binuclear triplet. 
The $\left(\mathrm{C}_{4} \mathrm{H}_{4} \mathrm{P}\right)_{2} \mathrm{Fe}_{2}(\mathrm{CO})_{3}$ structure 3T-5, lying $5.5 \mathrm{kcal} / \mathrm{mol}$ in energy above 3T-1, has two terminal pentahapto $\eta^{5}-\mathrm{C}_{4} \mathrm{H}_{4} \mathrm{P}$ rings and three terminal $\mathrm{CO}$ groups (Figure 3 and Table 2). The Fe-Fe distance of $2.589 \AA$ (B3LYP*) can be interpreted as a formal single bond. This gives each iron atom the 17-electron configuration for a binuclear triplet, provided that the iron atom bearing two $\mathrm{CO}$ groups has a formal positive charge and the iron atom bearing only one $\mathrm{CO}$ group has a formal negative charge.

Table 2. Total energies ( $\mathrm{E}$, in hartree), relative energies $(\Delta \mathrm{E}$, in $\mathrm{kcal} / \mathrm{mol}), \mathrm{Fe}-\mathrm{Fe}$ distances $(\AA)$, numbers of the imaginary vibrational frequencies (Nimg), and spin contamination values $\left(\left\langle\mathrm{S}^{2}\right\rangle\right)$ for the lowest energy $\left(\mathrm{C}_{4} \mathrm{H}_{4} \mathrm{P}\right)_{2} \mathrm{Fe}_{2}(\mathrm{CO})_{3}$ structures.

\begin{tabular}{cccccccc}
\hline & $\mathbf{3 T - 1}$ & $\mathbf{3 T - 2}$ & $\mathbf{3 T - 3}$ & $\mathbf{3 T - 4}$ & $\mathbf{3 T - 5}$ & $\mathbf{3 T - 6}$ & $\mathbf{3 S - 1}$ \\
& $\left(\mathrm{C}_{1},{ }^{3} \mathrm{~A}\right)$ & $\left(\mathrm{C}_{2},{ }^{3} \mathrm{~B}\right)$ & $\left(\mathrm{C}_{2 \mathrm{v}},{ }^{3} \mathrm{~B}_{1}\right)$ & $\left(\mathrm{C}_{2},{ }^{3} \mathrm{~B}\right)$ & $\left(\mathrm{C}_{1},{ }^{3} \mathrm{~A}\right)$ & $\left(\mathrm{C}_{1},{ }^{3} \mathrm{~A}\right)$ & $\left(\mathrm{C}_{1},{ }^{1} \mathrm{~A}\right)$ \\
\hline B3LYP* & & & & & & & \\
$-(\mathrm{E}+3859)$ & 0.15964 & 0.15809 & 0.15758 & 0.15142 & 0.15084 & 0.14843 & 0.14108 \\
$\Delta \mathrm{E}$ & 0.0 & 1.0 & 1.3 & 5.2 & 5.5 & 7.0 & 11.6 \\
$\mathrm{Fe}-\mathrm{Fe}$ & 2.609 & 2.270 & 2.267 & 2.460 & 2.589 & 2.564 & 2.447 \\
\hline $\mathrm{Nimg}$ & 0 & 0 & 0 & 1 & 0 & 0 & 0 \\
$\left\langle\mathrm{~S}^{2}\right\rangle$ & 2.1 & 2.1 & 2.1 & 2.1 & 2.3 & 2.1 & 0.0 \\
\hline
\end{tabular}

The $\left(\mathrm{C}_{4} \mathrm{H}_{4} \mathrm{P}\right)_{2} \mathrm{Fe}_{2}(\mathrm{CO})_{3}$ structure 3T-6, lying $7.0 \mathrm{kcal} / \mathrm{mol}(\mathrm{B} 3 \mathrm{LYP} *)$ in energy above 3T-1, has a bridging $\mathrm{CO}$ group and a terminal $\mathrm{CO}$ group bonded to each iron atom. One of the phospholyl rings in 3T-6 is a terminal pentahapto $\eta^{5}-\mathrm{C}_{4} \mathrm{H}_{4} \mathrm{P}$ ring whereas the other phospholyl ring is a seven-electron donor bridging $\eta^{5}, \eta^{1}-\mathrm{C}_{4} \mathrm{H}_{4} \mathrm{P}$ ring bonded to one iron atom as a pentahapto ligand and to the other iron atom through a dative $\mathrm{P} \rightarrow \mathrm{Fe}$ bond of length $2.464 \AA$. The Fe-Fe distance of $2.564 \AA$ (B3LYP*) suggests a formal single bond. The triplet spin state of 3T-6 can be rationalized by assigning the iron atom bonded to the terminal $\eta^{5}-\mathrm{C}_{4} \mathrm{H}_{4} \mathrm{P}$ ring a 19-electron configuration and the other iron atom a 17-electron configuration.

The lowest energy singlet $\left(\mathrm{C}_{4} \mathrm{H}_{4} \mathrm{P}\right)_{2} \mathrm{Fe}_{2}(\mathrm{CO})_{3}$ structure 3S-1, lying $11.6 \mathrm{kcal} / \mathrm{mol}$ (B3LYP*) in energy above 3T-1, has two bridging $\mathrm{CO}$ groups, one terminal $\mathrm{CO}$ group and two terminal pentahapto $\eta^{5}-\mathrm{C}_{4} \mathrm{H}_{4} \mathrm{P}$ rings (Figure 3 and Table 2). The $\mathrm{Fe}=\mathrm{Fe}$ distance in 3S-1 of $2.447 \AA$ (B3LYP*) is $\sim 0.13 \AA$ shorter than that in the doubly CO-bridged $\left(\mathrm{C}_{4} \mathrm{H}_{4} \mathrm{P}\right)_{2} \mathrm{Fe}_{2}(\mathrm{CO})_{2}(\mu-\mathrm{CO})_{2}$ structures and thus suggests a formal $\mathrm{Fe}=\mathrm{Fe}$ double bond in 3S-1. Each iron atom in 3S-1 has the favored 18-electron configuration provided that the iron atom bearing the terminal $\mathrm{CO}$ group has a formal positive charge and the other iron atom has a corresponding negative charge. 
3.1.3. $\left(\mathrm{C}_{4} \mathrm{H}_{4} P\right)_{2} \mathrm{Fe}_{2}(\mathrm{CO})_{2}$. Six low-energy $\left(\mathrm{C}_{4} \mathrm{H}_{4} \mathrm{P}\right)_{2} \mathrm{Fe}_{2}(\mathrm{CO})_{2}$ structures (two singlets and four triplets) were found within $20 \mathrm{kcal} / \mathrm{mol}$ in energy using the B3LYP* method (Figure 4 and Table 3). The $\left(\mathrm{C}_{4} \mathrm{H}_{4} \mathrm{P}\right)_{2} \mathrm{Fe}_{2}(\mathrm{CO})_{2}$ global minimum 2T-1 has two terminal $\mathrm{CO}$ groups and two seven-electron donor bridging $\eta^{1}, \eta^{5}-\mathrm{C}_{4} \mathrm{H}_{4} \mathrm{P}$ rings, bonded to one iron atom as a pentahapto ligand and to the other iron atom through a $\mathrm{P} \rightarrow \mathrm{Fe}$ dative bond of length $~ 2.37 \AA$. The Fe-Fe distance of $2.654 \AA$ (B3LYP*) can correspond to a relatively long formal single bond. However, if this Fe-Fe distance is interpreted as a nonbonding distance forced to be relatively short because of the geometry of the bridging $\eta^{5}, \eta^{1}-\mathrm{C}_{4} \mathrm{H}_{4} \mathrm{P}$ ligands, then each iron atom has a 17 -electron configuration consistent with a binuclear triplet.

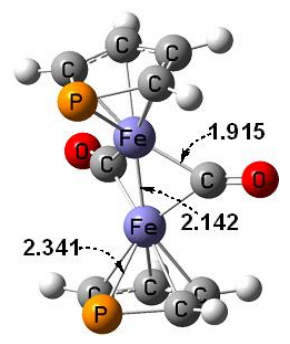

2S-1 $\left(C_{2 v}\right)$

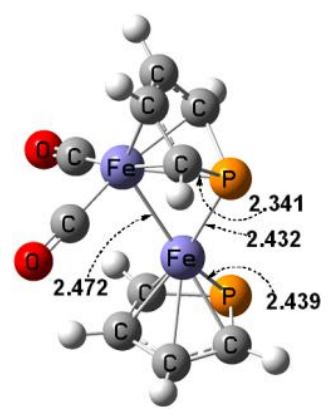

2T-2 $\left(C_{1}\right)$

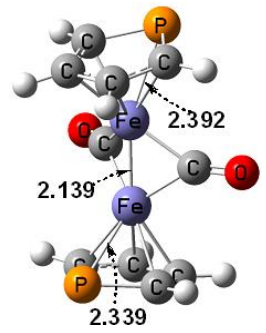

2S-2 $\left(C_{s}\right)$

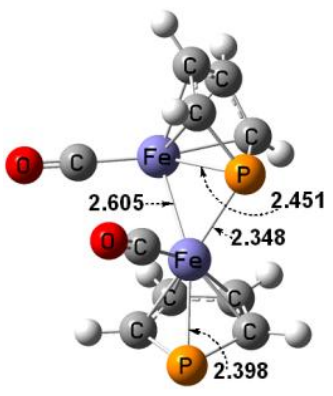

2T-3 $\left(C_{1}\right)$

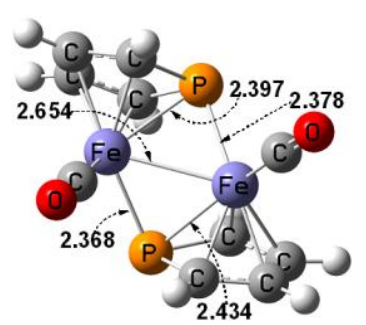

2T-1 $\left(C_{1}\right)$

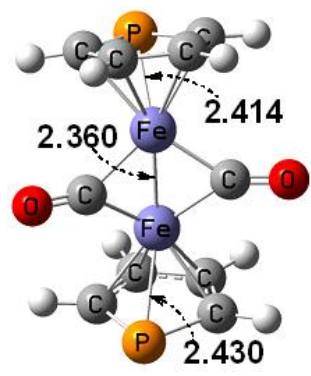

2T-4 $\left(C_{1}\right)$

Figure 4. The six lowest energy $\left(\mathrm{C}_{4} \mathrm{H}_{4} \mathrm{P}\right)_{2} \mathrm{Fe}_{2}(\mathrm{CO})_{2}$ structures.

Table 3. Total energies ( $E$, in hartree), relative energies $(\Delta E$, in $\mathrm{kcal} / \mathrm{mol})$, and $\mathrm{Fe}-\mathrm{Fe}$ distances $(\AA)$ for the six lowest energy $\left(\mathrm{C}_{4} \mathrm{H}_{4} \mathrm{P}\right)_{2} \mathrm{Fe}_{2}(\mathrm{CO})_{2}$ structures. None of these structures has any imaginary vibrational frequencies.

\begin{tabular}{ccccccc}
\hline & $\begin{array}{c}\mathbf{2 T}-1 \\
\left(C_{1},{ }^{3} \mathrm{~A}\right)\end{array}$ & $\begin{array}{c}\mathbf{2 T}-2 \\
\left(C_{1},{ }^{3} \mathrm{~A}\right)\end{array}$ & $\begin{array}{c}\mathbf{2 T}-\mathbf{3} \\
\left(C_{1},{ }^{3} \mathrm{~A}\right)\end{array}$ & $\begin{array}{c}\mathbf{2 T}-\mathbf{4} \\
\left(C_{1},{ }^{3} \mathrm{~A}\right)\end{array}$ & $\begin{array}{c}\mathbf{2 S}-\mathbf{1} \\
\left(C_{2 v},{ }^{1} \mathrm{~A}_{1}\right)\end{array}$ & $\begin{array}{c}\mathbf{2 S}-2 \\
\left(C_{s},{ }^{1} \mathrm{~A}^{\prime}\right)\end{array}$ \\
\hline $\mathrm{B}^{2} \mathrm{LYP} *$ & & & & & & \\
$-(\mathrm{E}+3745)$ & 0.84339 & 0.84038 & 0.83823 & 0.83544 & 0.82777 & 0.82684 \\
$\Delta \mathrm{E}$ & 0.0 & 1.9 & 3.2 & 5.0 & 9.8 & 10.4 \\
$\mathrm{Fe}-\mathrm{Fe}$ & 2.654 & 2.4720 & 2.605 & 2.360 & 2.142 & 2.139 \\
$\left\langle\mathrm{~S}^{2}\right\rangle$ & 2.1 & 2.3 & 3.1 & 2.8 & 0.0 & 0.0 \\
\hline
\end{tabular}


The $\left(\mathrm{C}_{4} \mathrm{H}_{4} \mathrm{P}\right)_{2} \mathrm{Fe}_{2}(\mathrm{CO})_{2}$ structure $\mathbf{2 T - 2}$, lying $1.9 \mathrm{kcal} / \mathrm{mol}$ in energy above $\mathbf{2 T - 1}$, has two terminal CO groups bonded to the same iron atom (Figure 4 and Table 3). One phospholyl ring in 2T-2 is a terminal pentahapto $\eta^{5}-\mathrm{C}_{4} \mathrm{H}_{4} \mathrm{P}$ ligand whereas the other phospholyl ring is a seven-electron donor bridging $\eta^{5}, \eta^{1}-\mathrm{C}_{4} \mathrm{H}_{4} \mathrm{P}$ ligand. The $\mathrm{Fe}-\mathrm{Fe}$ distance of $2.472 \AA$ (B3LYP*) suggest a formal single bond. This gives the iron atom bearing two terminal $\mathrm{CO}$ groups the favored 18-electron configuration, whereas the other iron atom has only a 16-electron configuration. The $\left(\mathrm{C}_{4} \mathrm{H}_{4} \mathrm{P}\right)_{2} \mathrm{Fe}_{2}(\mathrm{CO})_{2}$ structure 2T-3, lying $3.2 \mathrm{kcal} / \mathrm{mol}$ in energy above $\mathbf{2 T - 1}$ is similar to $\mathbf{2 T - 2}$ except that the terminal CO groups are distributed evenly between the two iron atoms. This leads to a longer $\mathrm{Fe}-\mathrm{Fe}$ single bond of $2.605 \AA$ in $\mathbf{2 T - 3}$ relative to $\mathbf{2 T - 2}$.

The $\left(\mathrm{C}_{4} \mathrm{H}_{4} \mathrm{P}\right)_{2} \mathrm{Fe}_{2}(\mathrm{CO})_{2}$ structure $2 \mathrm{~T}-\mathbf{4}$, lying $5.0 \mathrm{kcal} / \mathrm{mol}$ in energy above $\mathbf{2 T - 1}$, has two bridging $\mathrm{CO}$ groups and two terminal $\eta^{5}-\mathrm{C}_{4} \mathrm{H}_{4} \mathrm{P}$ rings (Figure 4 and Table 3 ). The $\mathrm{Fe}=\mathrm{Fe}$ distance of $2.360 \AA$ (B3LYP*) can be interpreted as a formal double bond. This gives each iron atom the 17-electron configuration for a binuclear triplet.

The lowest energy singlet $\left(\mathrm{C}_{4} \mathrm{H}_{4} \mathrm{P}\right)_{2} \mathrm{Fe}_{2}(\mathrm{CO})_{2}$ structure $\mathbf{2 S - 1}$, lying $9.8 \mathrm{kcal} / \mathrm{mol}$ in energy above $\mathbf{2 T - 1}$, is a $C_{2 v}$ structure with terminal pentahapto $\eta^{5}-\mathrm{C}_{4} \mathrm{H}_{4} \mathrm{P}$ rings and bridging $\mathrm{CO}$ groups similar to $\mathbf{2 T - 4}$ (Figure 4 and Table 3). The $\mathrm{Fe} \equiv \mathrm{Fe}$ distance of $2.142 \AA$ (B3LYP*) in 2S-1 is $\sim 0.2 \AA$ shorter than that in 2T-4. This suggests the formal triple bond required to give each iron atom the favored 18 -electron configuration. The singlet $\left(\mathrm{C}_{4} \mathrm{H}_{4} \mathrm{P}\right)_{2} \mathrm{Fe}_{2}(\mathrm{CO})_{2}$ structure $\mathbf{2 S - 2}$, lying $10.4 \mathrm{kcal} / \mathrm{mol}$ in energy above $\mathbf{2 T - 1}$, is similar to 2S-1 except for the orientation of the phosphorus atoms in the phospholyl rings.

\subsection{Carbonyl rich structures}

3.2.1 $\left(\mathrm{C}_{4} \mathrm{H}_{4} \mathrm{P}\right)_{2} \mathrm{Fe}_{2}(\mathrm{CO})_{6}$. Two low-energy structures (one singlet and one triplet) were found for $\left(\mathrm{C}_{4} \mathrm{H}_{4} \mathrm{P}\right)_{2} \mathrm{Fe}_{2}(\mathrm{CO})_{6}$ (Figure 5 and Table 4). The lower energy structure is the singlet 6S-1 with two bridging $\mathrm{CO}$ groups, four terminal $\mathrm{CO}$ groups, one pentahapto $\eta^{5}$ $\mathrm{C}_{4} \mathrm{H}_{4} \mathrm{P}$ ring, and one monohapto $\eta^{1}-\mathrm{C}_{4} \mathrm{H}_{4} \mathrm{P}$ ring. The monohapto $\eta^{1}-\mathrm{C}_{4} \mathrm{H}_{4} \mathrm{P}$ ring is bonded

to the iron atom bearing three terminal $\mathrm{CO}$ groups whereas the pentahapto $\eta^{5}-\mathrm{C}_{4} \mathrm{H}_{4} \mathrm{P}$ ring is bonded to the iron atom bearing a single terminal $\mathrm{CO}$ group. The $\mathrm{Fe}-\mathrm{Fe}$ distance of $2.638 \AA$ (B3LYP*) in 6S-1 suggests a formal single Fe-Fe bond leading to the favored 18 -electron configuration for each iron atom.

The triplet $\left(\mathrm{C}_{4} \mathrm{H}_{4} \mathrm{P}\right)_{2} \mathrm{Fe}_{2}(\mathrm{CO})_{6}$ structure 6T-1, lying $4.3 \mathrm{kcal} / \mathrm{mol}(\mathrm{B} 3 \mathrm{LYP} *)$ in energy above $\mathbf{6 S - 1}$, has six terminal $\mathrm{CO}$ groups equally distributed between two iron atoms (Figure 5 and Table 4). The bridging $\eta^{1}, \eta^{1}-\mathrm{C}_{4} \mathrm{H}_{4} \mathrm{P}$ ring in $\mathbf{6 T - 1}$, considered as a neutral ligand, donates a single electron to one iron atom and a pair of electrons (through the phosphorus lone pair) to the other iron atom. The $\eta^{1}-\mathrm{C}_{4} \mathrm{H}_{4} \mathrm{P}$ ring is bonded to one of 
the iron atoms and donates a single electron to that iron atom. The $\mathrm{Fe}-\mathrm{Fe}$ distance of $2.665 \AA$ (B3LYP*) suggests a formal single bond. This gives each iron atom in 6T-1 the 17-electron configuration for a binuclear triplet.

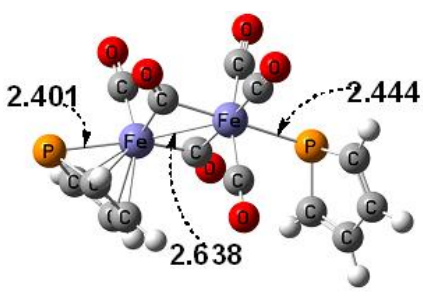

6S-1 $\left(C_{1}\right)$

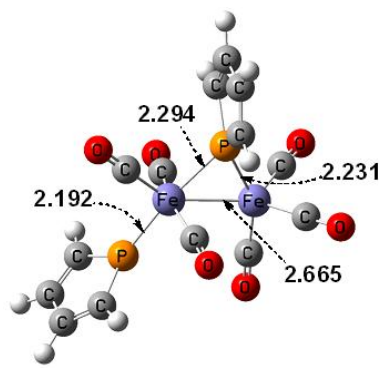

$6 \mathrm{~T}-1\left(C_{1}\right)$

Figure 5. The singlet and triplet $\left(\mathrm{C}_{4} \mathrm{H}_{4} \mathrm{P}\right)_{2} \mathrm{Fe}_{2}(\mathrm{CO})_{6}$ structures.

Table 4. Total energies ( $\mathrm{E}$, in hartree), relative Energies $(\Delta \mathrm{E}$, in $\mathrm{kcal} / \mathrm{mol}), \mathrm{Fe}-\mathrm{Fe}$ distances $(\AA)$, and spin contamination values $\left\langle\mathrm{S}^{2}\right\rangle$ for the two lowest energy $\left(\mathrm{C}_{4} \mathrm{H}_{4} \mathrm{P}\right)_{2} \mathrm{Fe}_{2}(\mathrm{CO})_{6}$ structures. Neither structure has any imaginary vibrational frequencies.

\begin{tabular}{ccc}
\hline \hline & $\mathbf{6 S - 1}$ & $\mathbf{6 T - 1}$ \\
& $\left(C_{1},{ }^{1} \mathrm{~A}\right)$ & $\left(C_{s},{ }^{3} \mathrm{~A}\right)$ \\
\hline B3LYP* & & \\
$-(\mathrm{E}+4199)$ & 0.04298 & 0.03606 \\
$\Delta \mathrm{E}$ & 0.0 & 4.3 \\
$\mathrm{Fe}-\mathrm{Fe}$ & 2.638 & 2.665 \\
\hline$\left\langle\mathrm{S}^{2}\right\rangle$ & 0.0 & 2.0 \\
\hline
\end{tabular}

3.2.2. $\left(\mathrm{C}_{4} \mathrm{H}_{4} \mathrm{P}\right)_{2} \mathrm{Fe}_{2}(\mathrm{CO})_{5}$. Two low-lying $\left(\mathrm{C}_{4} \mathrm{H}_{4} \mathrm{P}\right)_{2} \mathrm{Fe}_{2}(\mathrm{CO})_{5}$ singlet structures were found (Figure 6, Table 5). The lower energy structure 5S-1 has two bridging CO groups, and three terminal $\mathrm{CO}$ groups. A terminal monohapto $\eta^{1}-\mathrm{C}_{4} \mathrm{H}_{4} \mathrm{P}$ ring is bonded to the iron atom bearing two terminal $\mathrm{CO}$ groups with an unusually short $\mathrm{Fe}=\mathrm{P}$ bond of $2.143 \AA$. On the basis of this short $\mathrm{Fe}=\mathrm{P}$ distance, this phosphorus atom can be considered as a three-electron donor to the iron atom. A terminal pentahapto $\eta^{5}-\mathrm{C}_{4} \mathrm{H}_{4} \mathrm{P}$ ring is bonded to the iron atom bearing only a single terminal $\mathrm{CO}$ group. The $\mathrm{Fe}-\mathrm{Fe}$ distance of $2.592 \AA$ (B3LYP*) suggests a formal single bond, thereby giving each iron atom the favored 18-electron configuration.

The $\left(\mathrm{C}_{4} \mathrm{H}_{4} \mathrm{P}\right)_{2} \mathrm{Fe}_{2}(\mathrm{CO})_{5}$ structure 5S-2, lying $3.9 \mathrm{kcal} / \mathrm{mol}(\mathrm{B} 3 \mathrm{LYP} *)$ in energy above 5S-1, has two bridging $\mathrm{CO}$ groups and three terminal $\mathrm{CO}$ groups (Figure 6 and Table 5). One of the phospholyl ligands is a terminal pentahapto $\eta^{5}-\mathrm{C}_{4} \mathrm{H}_{4} \mathrm{P}$ ligand and is bonded to the iron atom bearing a single terminal $\mathrm{CO}$ group. The other phospholyl 
ligand is an unusual terminal dihapto $\eta^{2}-\mathrm{C}_{4} \mathrm{H}_{4} \mathrm{P}$ ligand that can function as a threeelectron donor if considered formally as a neutral ligand. The Fe-Fe distance of $2.596 \AA$ (B3LYP*) suggests a formal single bond, thereby giving each iron atom in $\mathbf{5 S - 2}$ the favored 18-electron configuration.

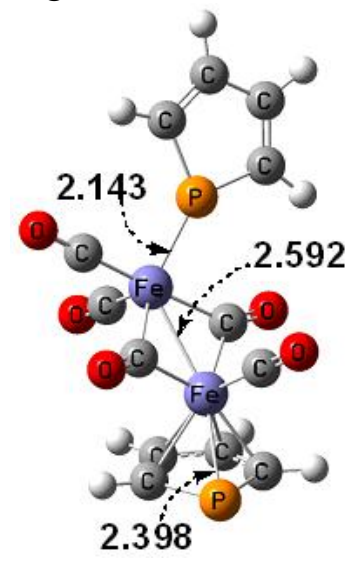

5S-1 $\left(C_{1}\right)$

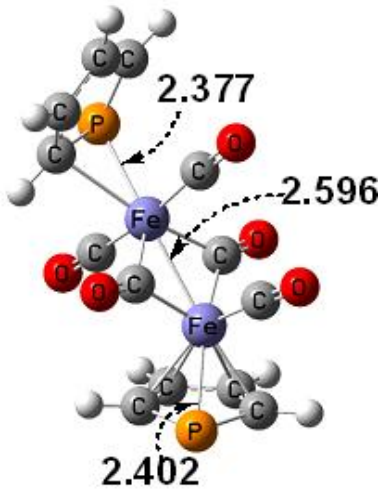

5S-2 $\left(C_{1}\right)$

Figure 6. The two optimized $\left(\mathrm{C}_{4} \mathrm{H}_{4} \mathrm{P}\right)_{2} \mathrm{Fe}_{2}(\mathrm{CO})_{5}$ structures.

Table 5. Total energies ( $E$, in hartree), relative energies $(\Delta E$, in $\mathrm{kcal} / \mathrm{mol})$, and $\mathrm{Fe}-\mathrm{Fe}$ distances $(\AA)$ for the two lowest energy $\left(\mathrm{C}_{4} \mathrm{H}_{4} \mathrm{P}\right)_{2} \mathrm{Fe}_{2}(\mathrm{CO})_{5}$ structures. Neither structure has any imaginary vibrational frequencies.

\begin{tabular}{lcc}
\hline & $\mathbf{5 S - 1}$ & $\mathbf{5 S - 2}$ \\
& $\left(C_{1},{ }^{1} \mathrm{~A}\right)$ & $\left(C_{1},{ }^{1} \mathrm{~A}\right)$ \\
\hline B3LYP* & & \\
$-(\mathrm{E}+4085)$ & 0.73984 & 0.73360 \\
$\mathrm{DE}$ & 0.0 & 3.9 \\
Fe-Fe & 2.592 & 2.596 \\
\hline
\end{tabular}

\subsection{Thermochemistry.}

Table 6 shows the dissociation energies for the reactions $\left(\mathrm{C}_{4} \mathrm{H}_{4} \mathrm{P}\right)_{2} \mathrm{Fe}_{2}(\mathrm{CO})_{n} \rightarrow$ $\left(\mathrm{C}_{4} \mathrm{H}_{4} \mathrm{P}\right)_{2} \mathrm{Fe}_{2}(\mathrm{CO})_{n-1}+\mathrm{CO}(n=6,5,4,3)$. The dissociation energy for the loss of one $\mathrm{CO}$ group from $\left(\mathrm{C}_{4} \mathrm{H}_{4} \mathrm{P}\right)_{2} \mathrm{Fe}_{2}(\mathrm{CO})_{5}$ is within $\sim 4 \mathrm{kcal} / \mathrm{mol}$ of being thermoneutral suggesting a species that is not viable. However, the $\mathrm{CO}$ dissociation energies for the other $\left(\mathrm{C}_{4} \mathrm{H}_{4} \mathrm{P}\right)_{2} \mathrm{Fe}_{2}(\mathrm{CO})_{n}$ species $(n=6,4,3)$ are all positive and greater than $\sim 22 \mathrm{kcal} / \mathrm{mol}$ suggesting viability towards $\mathrm{CO}$ dissociation. In fact, these predicted $\mathrm{CO}$ dissociation energies for the $\left(\mathrm{C}_{4} \mathrm{H}_{4} \mathrm{P}\right)_{2} \mathrm{Fe}_{2}(\mathrm{CO})_{n}$ derivatives $(n=6,4,3)$ are comparable to the experimental $\mathrm{CO}$ dissociation energies of 27,41 , and $37 \mathrm{kcal} / \mathrm{mol}$ for the stable metal carbonyls $\mathrm{Ni}(\mathrm{CO})_{4}, \mathrm{Fe}(\mathrm{CO})_{5}$, and $\mathrm{Cr}(\mathrm{CO})_{6}$, respectively [41]. 
Table 6. Dissociation energies $(\mathrm{kcal} / \mathrm{mol})$ for the successive removal of carbonyl groups from the $\left(\mathrm{C}_{4} \mathrm{H}_{4} \mathrm{P}\right)_{2} \mathrm{Fe}_{2}(\mathrm{CO})_{n}$ derivatives

\begin{tabular}{cccc}
\hline & B3LYP & BP86 & B3LYP* \\
\hline$\left(\mathrm{C}_{4} \mathrm{H}_{4} \mathrm{P}\right)_{2} \mathrm{Fe}_{2}(\mathrm{CO})_{6}(\mathbf{6 S - 1}) \rightarrow\left(\mathrm{C}_{4} \mathrm{H}_{4} \mathrm{P}\right)_{2} \mathrm{Fe}_{2}(\mathrm{CO})_{5}(\mathbf{5 S}-\mathbf{1})+\mathrm{CO}$ & 22.7 & 24.9 & 23.8 \\
$\left(\mathrm{C}_{4} \mathrm{H}_{4} \mathrm{P}\right)_{2} \mathrm{Fe}_{2}(\mathrm{CO})_{5}(\mathbf{5 S}-\mathbf{1}) \rightarrow\left(\mathrm{C}_{4} \mathrm{H}_{4} \mathrm{P}\right)_{2} \mathrm{Fe}_{2}(\mathrm{CO})_{4}(\mathbf{4 S}-\mathbf{1})+\mathrm{CO}$ & -3.8 & 1.5 & -1.7 \\
$\left(\mathrm{C}_{4} \mathrm{H}_{4} \mathrm{P}\right)_{2} \mathrm{Fe}_{2}(\mathrm{CO})_{4}(\mathbf{4 S - 1}) \rightarrow\left(\mathrm{C}_{4} \mathrm{H}_{4} \mathrm{P}\right)_{2} \mathrm{Fe}_{2}(\mathrm{CO})_{3}(\mathbf{3 S}-\mathbf{1})+\mathrm{CO}$ & 42.5 & 48.0 & 44.6 \\
$\left(\mathrm{C}_{4} \mathrm{H}_{4} \mathrm{P}\right)_{2} \mathrm{Fe}_{2}(\mathrm{CO})_{3}(\mathbf{3 T - 1}) \rightarrow\left(\mathrm{C}_{4} \mathrm{H}_{4} \mathrm{P}\right)_{2} \mathrm{Fe}_{2}(\mathrm{CO})_{2}(\mathbf{2 T}-\mathbf{1})+\mathrm{CO}$ & 23.6 & 44.7 & 32.0 \\
$\left(\mathrm{C}_{4} \mathrm{H}_{4} \mathrm{P}\right)_{2} \mathrm{Fe}_{2}(\mathrm{CO})_{3}(\mathbf{3 S}-\mathbf{1}) \rightarrow\left(\mathrm{C}_{4} \mathrm{H}_{4} \mathrm{P}\right)_{2} \mathrm{Fe}_{2}(\mathrm{CO})_{2}(\mathbf{2 S}-\mathbf{1})+\mathrm{CO}$ & 27.9 & 34.8 & 30.2 \\
\hline
\end{tabular}

Table 7 lists the energies for the disproportionation reactions $2\left(\mathrm{C}_{4} \mathrm{H}_{4} \mathrm{P}\right)_{2} \mathrm{Fe}_{2}(\mathrm{CO})_{n}$ $\rightarrow\left(\mathrm{C}_{4} \mathrm{H}_{4} \mathrm{P}\right)_{2} \mathrm{Fe}_{2}(\mathrm{CO})_{n+1}+\left(\mathrm{C}_{4} \mathrm{H}_{4} \mathrm{P}\right)_{2} \mathrm{Fe}_{2}(\mathrm{CO})_{n-1}(n=5,4,3)$. This process is strongly endothermic for the tetracarbonyl $\left(\mathrm{C}_{4} \mathrm{H}_{4} \mathrm{P}\right)_{2} \mathrm{Fe}_{2}(\mathrm{CO})_{4}$ at $\sim 46 \mathrm{kcal} / \mathrm{mol}$ indicating the tetracarbonyl to be a viable species. The disproportionations of the tricarbonyl and pentacarbonyl $\left(\mathrm{C}_{4} \mathrm{H}_{4} \mathrm{P}\right)_{2} \mathrm{Fe}_{2}(\mathrm{CO})_{n}(n=5,3)$ are exothermic suggesting that they are not viable species.

Table 7. Disproportionation Energies $(\mathrm{kcal} / \mathrm{mol})$ for the reactions $2\left(\mathrm{C}_{4} \mathrm{H}_{4} \mathrm{P}\right)_{2} \mathrm{Fe}_{2}(\mathrm{CO})_{n} \rightarrow$ $\left(\mathrm{C}_{4} \mathrm{H}_{4} \mathrm{P}\right)_{2} \mathrm{Fe}_{2}(\mathrm{CO})_{n+1}+\left(\mathrm{C}_{4} \mathrm{H}_{4} \mathrm{P}\right)_{2} \mathrm{Fe}_{2}(\mathrm{CO})_{n-1}$

\begin{tabular}{lccc}
\hline \hline & B3LYP & BP86 & B3LYP* \\
\hline $2\left(\mathrm{C}_{4} \mathrm{H}_{4} \mathrm{P}\right)_{2} \mathrm{Fe}_{2}(\mathrm{CO})_{5}(\mathbf{5 S - 1}) \rightarrow\left(\mathrm{C}_{4} \mathrm{H}_{4} \mathrm{P}\right)_{2} \mathrm{Fe}_{2}(\mathrm{CO})_{4}(\mathbf{4 S - 1})+\left(\mathrm{C}_{4} \mathrm{H}_{4} \mathrm{P}\right)_{2} \mathrm{Fe}_{2}(\mathrm{CO})_{6}(\mathbf{6 S - 1})$ & -26.5 & -23.4 & -25.5 \\
$2\left(\mathrm{C}_{4} \mathrm{H}_{4} \mathrm{P}\right)_{2} \mathrm{Fe}_{2}(\mathrm{CO})_{4}(\mathbf{4 S - 1}) \rightarrow\left(\mathrm{C}_{4} \mathrm{H}_{4} \mathrm{P}\right)_{2} \mathrm{Fe}_{2}(\mathrm{CO})_{3}(\mathbf{3 S}-\mathbf{1})+\left(\mathrm{C}_{4} \mathrm{H}_{4} \mathrm{P}\right)_{2} \mathrm{Fe}_{2}(\mathrm{CO})_{5}(\mathbf{5 S}-\mathbf{1})$ & 46.3 & 46.4 & 46.3 \\
$2\left(\mathrm{C}_{4} \mathrm{H}_{4} \mathrm{P}\right)_{2} \mathrm{Fe}_{2}(\mathrm{CO})_{3}(\mathbf{3 S}-\mathbf{1}) \rightarrow\left(\mathrm{C}_{4} \mathrm{H}_{4} \mathrm{P}\right)_{2} \mathrm{Fe}_{2}(\mathrm{CO})_{2}(\mathbf{2 S}-\mathbf{1})+\left(\mathrm{C}_{4} \mathrm{H}_{4} \mathrm{P}\right)_{2} \mathrm{Fe}_{2}(\mathrm{CO})_{4}(\mathbf{4 S}-\mathbf{1})$ & -14.6 & -13.2 & -14.4 \\
$2\left(\mathrm{C}_{4} \mathrm{H}_{4} \mathrm{P}\right)_{2} \mathrm{Fe}_{2}(\mathrm{CO})_{3}(\mathbf{3 T}-\mathbf{1}) \rightarrow\left(\mathrm{C}_{4} \mathrm{H}_{4} \mathrm{P}\right)_{2} \mathrm{Fe}_{2}(\mathrm{CO})_{2}(\mathbf{2 T}-\mathbf{1})+\left(\mathrm{C}_{4} \mathrm{H}_{4} \mathrm{P}\right)_{2} \mathrm{Fe}_{2}(\mathrm{CO})_{4}(\mathbf{4 S}-\mathbf{1})$ & -7.8 & 5.4 & -0.9 \\
\hline
\end{tabular}

Also of interest is the dissociation of the $\left(\mathrm{C}_{4} \mathrm{H}_{4} \mathrm{P}\right)_{2} \mathrm{Fe}_{2}(\mathrm{CO})_{n}$ derivatives into mononuclear $\left(\mathrm{C}_{4} \mathrm{H}_{4} \mathrm{P}\right) \mathrm{Fe}(\mathrm{CO})_{m}$ fragments. In order to obtain such energetic data, the structures of the mononuclear $\left(\mathrm{C}_{4} \mathrm{H}_{4} \mathrm{P}\right) \mathrm{Fe}(\mathrm{CO})_{m}$ were optimized by the same DFT methods as used to study the binuclear derivatives (Figure 7). Using this information, the dissociation energies of the binuclear $\left(\mathrm{C}_{4} \mathrm{H}_{4} \mathrm{P}\right)_{2} \mathrm{Fe}_{2}(\mathrm{CO})_{n}$ into mononuclear fragments were determined (Table 8). The results were found to depend on the density functional used since the mononuclear $\left(\mathrm{C}_{4} \mathrm{H}_{4} \mathrm{P}\right) \mathrm{Fe}(\mathrm{CO})_{n}$ are necessarily doublet spin state structures and energy differences between different spin state isomers are dependent on the density functional used. However, dissociation of the pentacarbonyl $\left(\mathrm{C}_{4} \mathrm{H}_{4} \mathrm{P}\right)_{2} \mathrm{Fe}_{2}(\mathrm{CO})_{5}$ into the mononuclear fragments $\left(\mathrm{C}_{4} \mathrm{H}_{4} \mathrm{P}\right) \mathrm{Fe}(\mathrm{CO})_{3}$ and $\left(\mathrm{C}_{4} \mathrm{H}_{4} \mathrm{P}\right) \mathrm{Fe}(\mathrm{CO})_{2}$ appears to be either slightly exothermic (B3LYP) or nearly thermoneutral (B3LYP*) by two of the DFT 
methods and the least endothermic $(16.9 \mathrm{kcal} / \mathrm{mol})$ by the BP86 method. The other $\left(\mathrm{C}_{4} \mathrm{H}_{4} \mathrm{P}\right)_{2} \mathrm{Fe}_{2}(\mathrm{CO})_{n}(n=6,4,3,2)$ appear to be viable with respect to dissociation into mononuclear fragments with the dissociation energies increasing with decreasing numbers of $\mathrm{CO}$ groups similar to related systems.
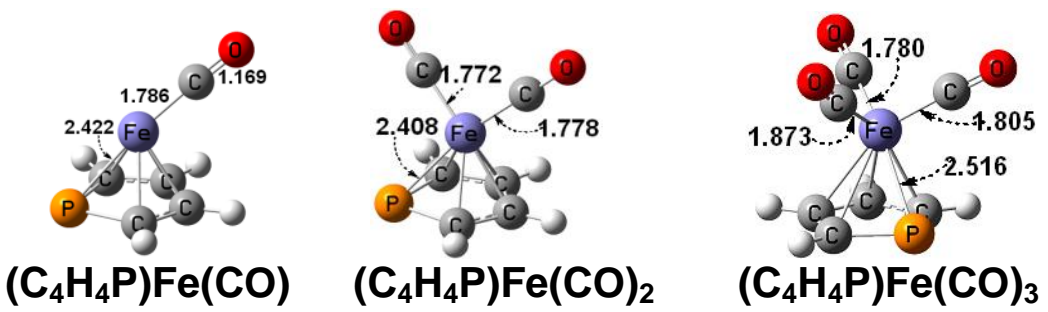

Figure 7. The optimized geometries for the mononuclear structures $\left(\mathrm{C}_{4} \mathrm{H}_{4} \mathrm{P}\right) \mathrm{Fe}(\mathrm{CO})_{m}(m=$ $3,2,1)$.

Table 8. Dissociation energies of the binuclear $\left(\mathrm{C}_{4} \mathrm{H}_{4} \mathrm{P}\right)_{2} \mathrm{Fe}_{2}(\mathrm{CO})_{n}(n=5,4,3,2)$ into mononuclear fragments $(\mathrm{kcal} / \mathrm{mol})$

\begin{tabular}{cccc}
\hline \hline & B3LYP & BP86 & B3LYP* \\
\hline$\left(\mathrm{C}_{4} \mathrm{H}_{4} \mathrm{P}\right)_{2} \mathrm{Fe}_{2}(\mathrm{CO})_{6}(\mathbf{6 S - 1}) \rightarrow 2\left(\mathrm{C}_{4} \mathrm{H}_{4} \mathrm{P}\right) \mathrm{Fe}(\mathrm{CO})_{3}$ & 7.0 & 23.1 & 12.5 \\
$\left(\mathrm{C}_{4} \mathrm{H}_{4} \mathrm{P}\right)_{2} \mathrm{Fe}_{2}(\mathrm{CO})_{5}(\mathbf{5 S - 1}) \rightarrow\left(\mathrm{C}_{4} \mathrm{H}_{4} \mathrm{P}\right) \mathrm{Fe}(\mathrm{CO})_{2}+\left(\mathrm{C}_{4} \mathrm{H}_{4} \mathrm{P}\right) \mathrm{Fe}(\mathrm{CO})_{3}$ & -6.0 & 16.9 & 1.2 \\
$\left(\mathrm{C}_{4} \mathrm{H}_{4} \mathrm{P}\right)_{2} \mathrm{Fe}_{2}(\mathrm{CO})_{4}(\mathbf{4 S - 1}) \rightarrow 2\left(\mathrm{C}_{4} \mathrm{H}_{4} \mathrm{P}\right) \mathrm{Fe}(\mathrm{CO})_{2}$ & 7.5 & 34.0 & 15.3 \\
$\left(\mathrm{C}_{4} \mathrm{H}_{4} \mathrm{P}\right)_{2} \mathrm{Fe}_{2}(\mathrm{CO})_{3}(\mathbf{3 T - 1}) \rightarrow\left(\mathrm{C}_{4} \mathrm{H}_{4} \mathrm{P}\right) \mathrm{Fe}(\mathrm{CO})_{2}+\left(\mathrm{C}_{4} \mathrm{H}_{4} \mathrm{P}\right) \mathrm{Fe}(\mathrm{CO})$ & 29.7 & 57.0 & 39.2 \\
$\left(\mathrm{C}_{4} \mathrm{H}_{4} \mathrm{P}\right)_{2} \mathrm{Fe}_{2}(\mathrm{CO})_{2}(\mathbf{2 S}-\mathbf{1}) \rightarrow 2\left(\mathrm{C}_{4} \mathrm{H}_{4} \mathrm{P}\right) \mathrm{Fe}(\mathrm{CO})$ & 44.4 & 75.7 & 54.3 \\
\hline
\end{tabular}

\subsection{NBO Analysis of the Iron-Iron Bonding}

Table 9 lists the atomic natural charges for the iron atoms and the Wiberg Bond Indices (WBI) for the Fe-Fe bonds using NBO analysis with the B3LYP* functional [42]. The Fe-Fe distances, the formal Fe-Fe bond orders, and the bridging groups are also listed for comparison. Only the singlet structures are considered since WBI analyses of higher spin state structures appear to be less reliable.

Previous studies on the Wiberg Bond Indices (WBIs) of metal carbonyls such as $\mathrm{Fe}_{2}(\mathrm{CO})_{9}$ and $\mathrm{Fe}_{3}(\mathrm{CO})_{12}$ show that the WBI values are relatively low compared with the formal bond orders, particularly when the metal-metal bonds are bridged by carbonyl groups [43]. This is also true for the $\left(\mathrm{C}_{4} \mathrm{H}_{4} \mathrm{P}\right)_{2} \mathrm{Fe}_{2}(\mathrm{CO})_{n}$ derivatives, with no WBI values greater than 0.6. However, the relative WBIs of the iron-iron bonds still correlate well with the formal bond orders suggested by Fe-Fe distances and electron counting.

The WBI values for the Fe-Fe bonds in the $\left(\mathrm{C}_{4} \mathrm{H}_{4} \mathrm{P}\right)_{2} \mathrm{Fe}_{2}(\mathrm{CO})_{n}$ derivatives depend on the formal bond order and the number of bridging groups (Table 9). Increasing the number of bridging groups generally lowers the WBI values, presumably because of 
multicenter bonding involving the bridging group and the iron atoms. Most of the structures reported in this paper have two bridging CO groups with WBI values for formal $\mathrm{Fe}-\mathrm{Fe}$ single bonds ranging from 0.13 to 0.20 . The formal $\mathrm{Fe}=\mathrm{Fe}$ double bond in 3S-2 and the formal $\mathrm{Fe} \equiv \mathrm{Fe}$ triple bonds in $\mathbf{2 S - 1}$ and $\mathbf{2 S - 2}$, all with two $\mathrm{CO}$ bridges, have correspondingly higher WBIs of 0.28 and 0.67 , respectively. The unbridged $\mathrm{Fe}-\mathrm{Fe}$ single bonds in the $\left(\mathrm{C}_{4} \mathrm{H}_{4} \mathrm{P}\right)_{2} \mathrm{Fe}_{2}(\mathrm{CO})_{4}$ structures have higher WBIs than doubly CO-bridged Fe-Fe single bonds, ranging from 0.30 to 0.32 . The relatively high energy $\left(\mathrm{C}_{4} \mathrm{H}_{4} \mathrm{P}\right)_{2} \mathrm{Fe}_{2}(\mathrm{CO})_{4}$ structure $\mathbf{4 S - 8}$ having two bridging phospholyl ligands and a long nonbonding $\mathrm{Fe}^{\cdots}{ }^{\cdots} \mathrm{Fe}$ distance of $3.871 \AA$ A has a nearly zero WBI of 0.02 .

Table 9. Atomic charges and Wiberg bond indices for the singlet $\left(\mathrm{C}_{4} \mathrm{H}_{4} \mathrm{P}\right)_{2} \mathrm{Fe}_{2}(\mathrm{CO})_{n}$ structures by the BP86 method.

\begin{tabular}{lccccc}
\hline & $\begin{array}{c}\text { Natural Charge on } \\
\text { Fe / Fe }\end{array}$ & $\begin{array}{c}\text { Wiberg bond } \\
\text { index }\end{array}$ & $\begin{array}{c}\text { Fe-Fe } \\
\text { distance, } \AA\end{array}$ & Bridges & $\begin{array}{c}\text { Bond } \\
\text { order }\end{array}$ \\
\hline $\mathbf{6 S - 1}$ & $-0.24 /-0.54$ & 0.13 & 2.638 & $2 \mathrm{CO}$ & 1 \\
$\mathbf{5 S - 1}$ & $-0.32 /-0.24$ & 0.15 & 2.592 & $2 \mathrm{CO}$ & 1 \\
$\mathbf{5 S - 2}$ & $-0.25 /-0.34$ & 0.19 & 2.596 & $2 \mathrm{CO}$ & 1 \\
$\mathbf{4 S - 1}$ & $-0.24 /-0.23$ & 0.20 & 2.573 & $2 \mathrm{CO}$ & 1 \\
$\mathbf{4 S - 2}$ & $-0.23 /-0.23$ & 0.20 & 2.568 & $2 \mathrm{CO}$ & 1 \\
$\mathbf{4 S - 3}$ & $-0.22 /-0.22$ & 0.20 & 2.574 & $2 \mathrm{CO}$ & 1 \\
$\mathbf{4 S - 4}$ & $-0.25 /-0.25$ & 0.30 & 2.770 & none & 1 \\
$\mathbf{4 S - 5}$ & $-0.24 /-0.24$ & 0.32 & 2.757 & none & 1 \\
$\mathbf{4 S - 6}$ & $-0.24 /-0.24$ & 0.32 & 2.759 & none & 1 \\
$\mathbf{4 S - 7}$ & $-0.23 /-0.23$ & 0.34 & 2.749 & none & 1 \\
$\mathbf{4 S - 8}$ & $-0.39 /-0.36$ & 0.02 & 3.871 & $2 \mathrm{C}_{4} \mathrm{H}_{4} \mathrm{P}$ & 0 \\
$\mathbf{3 S - 1}$ & $0.11 /-0.27$ & 0.28 & 2.447 & $2 \mathrm{CO}$ & 2 \\
$\mathbf{2 S - 1}$ & $-0.02 /-0.02$ & 0.67 & 2.142 & $2 \mathrm{CO}$ & 3 \\
$\mathbf{2 S - 2}$ & $-0.01 /-0.02$ & 0.67 & 2.139 & $2 \mathrm{CO}$ & 3 \\
\hline
\end{tabular}

\section{Summary}

The low-energy $\left(\mathrm{C}_{4} \mathrm{H}_{4} \mathrm{P}\right)_{2} \mathrm{Fe}_{2}(\mathrm{CO})_{n}(n=4,3,2)$ structures have direct iron-iron bonds and terminal five-electron donor pentahapto $\eta^{5}-\mathrm{C}_{4} \mathrm{H}_{4} \mathrm{P}$ rings with the phosphorus lone pairs not involved in the bonding to the iron atoms. They are thus analogous to the corresponding cyclopentadienyl derivatives. However, they differ from the binuclear phospholyl manganese carbonyls $\left(\mathrm{C}_{4} \mathrm{H}_{4} \mathrm{P}\right)_{2} \mathrm{Mn}_{2}(\mathrm{CO})_{n}(n=5,4)$, for which structures with bridging seven-electron donor $\eta^{5}, \eta^{1}-\mathrm{C}_{4} \mathrm{H}_{4} \mathrm{P}$ phospholyl rings using the phosphorus lone pairs as well as the ring $\pi$-electrons for ligand-manganese bonding are greatly favored energetically. 
Partially bonded phospholyl rings, as well as direct Fe-Fe bonds, are found in the carbonyl-rich $\left(\mathrm{C}_{4} \mathrm{H}_{4} \mathrm{P}\right)_{2} \mathrm{Fe}_{2}(\mathrm{CO})_{n}(n=6,5)$ species. The pentacarbonyl $\left(\mathrm{C}_{4} \mathrm{H}_{4} \mathrm{P}\right)_{2} \mathrm{Fe}_{2}(\mathrm{CO})_{5}$ does not appear to be a viable species since loss of $\mathrm{CO}$ to give $\left(\mathrm{C}_{4} \mathrm{H}_{4} \mathrm{P}\right)_{2} \mathrm{Fe}_{21}(\mathrm{CO})_{4}$ is essentially thermoneutral and disproportionation into $\left(\mathrm{C}_{4} \mathrm{H}_{4} \mathrm{P}\right)_{2} \mathrm{Fe}_{2}(\mathrm{CO})_{6}+$ $\left(\mathrm{C}_{4} \mathrm{H}_{4} \mathrm{P}\right)_{2} \mathrm{Fe}_{2}(\mathrm{CO})_{4}$ is significantly exothermic at $\sim 25 \mathrm{kcal} / \mathrm{mol}$.

Acknowledgment. We are indebted to the Scientific Research Fund of the Key Laboratory of the Education Department of Sichuan Province (Grant No. 10ZX012) and the U. S. National Science Foundation (Grant CHE-1057466) for the support of this research.

\section{Literature References}

[1] T. S. Piper, G. Wilkinson, J. Inorg. Nucl. Chem., 6 (1956) 104.

[2] O. S. Mills, Acta Cryst. 11 (1958) 620.

[3] R. F. Bryan, P. T. Greene, J. Chem. Soc., A, (1970) 3068.

[4] A. Mitschler, B. Rees, M. S. Lehmann, J. Am. Chem. Soc. 100 (1978) 3390.

[5] J. V. Caspar, T. J. Meyer, J. Am. Chem. Soc. 102 (1980) 7794.

[6] R. H. Hooker, K. A. Mahmoud, A. J. Rest, Chem. Commun. (1983) 1022.

[7] A. F. Hepp, J. P. Blaha, C. Lewis, M. S. Wrighton, M. S. Organometallics 3 (1984) 174.

[8] J. P. Blaha, B. E. Bursten, J. C. Dewan, R. B. Frankel, C. L. Randolph, B. A. Wilson, M. S. Wrighton, J. Am. Chem. Soc. 107 (1985) 4561.

[9] R. B. King, Inorg. Chem. 5 (1966) 2227. 
[10] H. Wang, Y. Xie, R. B. King, H. F. Schaefer,. Inorg. Chem., 45 (2006) 3384.

[11] K.B. Dillon, F. Mathey, J.F. Nixon, Phosphorus: The Carbon Copy: From Organophosphorus to Phospha-organic Chemistry, Wiley VCH, New York, 1998.

[12] F. Mathey, Tetrahedron Lett. (1976) 4155.

[13] F. Mathey, A. Mitschler, R. Weiss, J. Am. Chem. Soc. 100 (1978) 5748.

[14] X. Chen, Q. Du, R. Jin, H. Feng, Y. Xie, R. B. King, New J. Chem., 35 (2011) 1117.

[15] I. Bernal, J. D. Korp, W. A. Hermann, R. Serrano, Chem. Ber. 117 (1984) 434.

[16] X. Chen, R. Jin, Q. Du, H. Feng,Y. Xie, R. B. King, J. Organometal. Chem., 701 (2012) 1 .

[17] A. A. Bengali, R. G. Bergman, C. B. Moore, J. Am. Chem. Soc. 117 (1995) 3879.

[18] W.I. Bailey, D.M. Collins, F.A. Cotton, J.C. Baldwin, J. Organometal. Chem. 165 (1979) 373.

[19] H. Wang, Y. Xie, R.B. King, H.F. Schaefer, J. Am. Chem. Soc. 127 (2005) 11646.

[20] T. Ziegler, J. Autschbach, Chem. Rev., 105 (2005) 2695.

[21] M. Bühl, H. Kabrede, J. Chem. Theory Comput., 2 (2006) 1282.

[22] M. Brynda, L. Gagliardi, P. O. Widmark, P. P. Power, B. O. Roos, Angew. Chem. Int. Ed., 45 (2006) 3804.

[23] N. Sieffert, M. Bühl, J. Am. Chem. Soc., 132 (2010) 8056.

[24] P. Schyman, W. Lai, H. Chen, Y. Wang, S. Shaik, J. Am. Chem. Soc., 133 (2011) 7977.

[25] R. D. Adams, W. C. Pearl, Y.O. Wong, Q. Zhang, M. B. Hall, J. R. Walensky, J. Am. Chem. Soc., 133 (2011) 12994.

[26] R. Lonsdale, J. Olah, A. J. Mulholland, J. N. Harvey, J. Am. Chem. Soc., 133 (2011) 15464.

[27] A.D. Becke, J. Chem. Phys. 98 (1993) 5648.

[28] C. Lee, W. Yang, R.G. Parr, Phys. Rev. B 37 (1988) 785.

[29] A.D. Becke, Phys. Rev. 38 (1988) 3098.

[30] C. Lee, W. Yang, R. G. Parr, Phys. Rev. B. 37 (1988) 785.

[31] M. Reiher, O. Salomon, B. A. Hess, Theor. Chem.Acc. 107 (2001) 48.

[32] O. Salomon, M. Reiher, B. A. Hess, J. Chem. Phys. 117 (2002) 4729.

[33] V. Jones, W. Thiel, J. Phys. Chem., 102 (1995) 8474.

[34] I. Silaghi-Dumitrescu, T. E. Bitterwolf, R. B. King, J. Am. Chem. Soc., 128 (2006) 5432.

[35] T. H. Dunning, J. Chem. Phys. 53 (1970) 2823. 
[36] S. Huzinaga, J. Chem. Phys., 42 (1965) 1293.

[37] A. J. H. Wachters, J. Chem. Phys. 52 (1970) 1033.

[38] D. M. Hood, R. M. Pitzer, H. F. Schaefer, J. Chem. Phys. 71 (1979) 705.

[39] M. J. Frisch, et al. Gaussian, Inc., Wallingford CT, 2009. Gaussian 09, Revision A.02.

[40] B. N. Papas, H. F. Schaefer, J. Mol. Struct. (THEOCHEM) 768 (2006) 175.

[41] L. S. Sunderlin, D. Wang, P. R. Squires, J. Am. Chem. Soc., 115(1993) 12060.

[42] F. Weinhold, C. R. Landis, Valency and Bonding: A Natural Bond Order DonorAcceptor Perspective, Cambridge University Press, Cambridge, England, U. K., 2005, pp. 32-36.

[43] H. Wang, Y. Xie, R. B. King, H. F. Schaefer, J. Am. Chem. Soc. 128 (2006) 11376. 


\section{Graphical abstract}

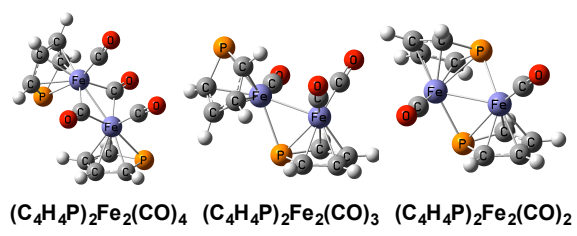

